\title{
Model Pembelajaran Make A Match Berbantuan Media Kartu Gambar Meningkatkan Hasil Belajar Matematika
}

\author{
I Made Adistha Gosachi ${ }^{1}$, I Gusti Ngurah Japa² \\ ${ }^{1}$ Prodi Pendidikan Guru Sekolah Dasar, Universitas Pendidikan Ganesha \\ Singaraja, Indonesia \\ e-mail: adisthagosachi9@gmail.com¹, igustingurah.japa@undiksha.ac.id²
}

\begin{abstract}
Abstrak
Pembelajaran berlangsung kurang efektif sehingga siswa mengalami kendala ketika menerima atau memahami materi matematika, kurangnya partisipasi serta keaktifan siswa dalam proses pembelajaran, dipertengahan pembelajaran siswa kurang memperhatikan pembelajaran, kurangnya penggunaan media menyebabkan semangat belajar siswa menurun dan cepat bosan sehingga berdampak terhadap hasil belajar siswa, tidak semua siswa bisa berkonsentrasi dalam waktu yang relatif lama dan kemampuan pemahaman peserta didik dalam mata pelajaran matematika berbeda-beda. Sehingga penelitian ini bertujuan untuk mengetahui pengaruh model pembelajaran Make A Match berbantuan media kartu gambar terhadap hasil belajar matematika pada siswa kelas IV SD. Jenis penelitian adalah ekperimen semu (Quasi Eksperiment) dengan desain post-test only control group design. Populasi dari penelitian ini adalah seluruh siswa kelas IV SD yang berjumlah 70 siswa. Penentuan sampel penelitian dilakukan dengan teknik sampling purposive. Dalam penelitian ini, pengumpulan data dilakukan menggunakan metode tes objektif berupa tes pilihan ganda. Data yang telah terkumpul selanjutnya dianalisis menggunakan analisis statistik deskriptif dan inferensial yaitu uji-t. Berdasarkan analisis deskriptif, diperoleh bahwa retata skor kelompok eksperimen lebih besar dibandingkan dengan retata kelompok kontrol $(19,47>17,59)$. Uji-t diperoleh hasil bahwa $t=2,65$, dan $p$ (taraf signifikan 5\%) =1,995. Dapat disimpulkan bahwa model pembelajaran Make A Match berbantuan Media Kartu Gambar berpengaruh terhadap hasil belajar matematika siswa kelas IV di SD Lab Singaraja. Model model pembelajaran Make A Match berbantuan Media Kartu Gambar dapat diaplikasikan pada pelajaran matematika di sekolah dasar sebagai upaya untuk meningkatkan hasil belajar siswa secara maksimal pada pelajaran matematika.
\end{abstract}

Kata kunci: MAM, gambar, hasil belajar matematika

\begin{abstract}
The research was aimed to know the difference of mathematics learning outocomes between the students who are tought by using the learning model Make A Match media picture card and the students who were not tought by using the learning model Make $A$ Match students in grade IV. The type of research is a pseudo-experimen (Quasi experiment) with a post-test only control group design. The population of this study was students in grade IV in SD Lab Singaraja in academic year 2019/2020 lesson amounting to 70 students. The research sampling was done by sampling technique purposive, The sample wad chosen by using sampling technique purosive. Students in grade IV $A$ as an experimental group with 36 students and students in grade IV B with the number of 34 students as the control group. The expetimental grup was students in grade IV A which consists of 36 students while the control group was students in grade IV B which consist of 34 students. In this study, data collection was conducted by using objective test method in the form of multiple choice test. The Data that has been accumulated is further analyzed using a descriptive statistical analysis and inferential i.e. $t$-test. Based on a descriptive analysis, it was acquired that the experiment Group's score was greater than the mean of the control group (19.47 > 17.59). T-test obtained the outocomes that $t=2.65$, and $p$ (significant level $5 \%$ ) = 1.995. It can be concluded that the learning model of Make A Match media picture card give an influence mathemstics learning outcomes of students in grade
\end{abstract}


IV in SD Lab Singaraja. Therefore, the learning model of Make A Match learning model supported by picture card media is suitable to be applied to overcome low mathematics learning outcomes.

Keywords: MAM, picture, learning outocomes mathematics

\section{Pendahuluan}

Matematika sebagai salah satu bidang studi yang diajarkan di lembaga pendidikan formal merupakan salah satu bagian penting dalam upaya meningkatkan mutu pendidikan. Pelajaran matematika merupakan suatu pelajaran yang berhubungan dengan banyak konsep. Konsep merupakan ide abstrak yang dengannya kita dapat mengelompokkan obyek-obyek kedalam contoh atau bukan contoh dimana konsep-konsep dalam matematika memiliki keterkaitan satu dengan yang lainnya (Novitasari, 2016: 8). Oleh karena itu, siswa harus memahami materi awal matematika sebelum melajutkan ke konsep berikutnya atau materi prasyarat dari materi yang akan pelajari. Adapun tujuan pembelajaran matematika di sekolah dasar adalah siswa mampu dan terampil menggunakan matematika, dapat memberikan tekanan penataran nalar dalam penerapan matematika, serta mampu menguasai konsep dari matematika (Susanto, 2013: 189). Agar tercapainya tujuan matematika tersebut, peran seorang guru sangat diperlukan. Seorang guru hendaknya dapat menciptakan kondisi dan situasi pembelajaran yang kondusif, agar dalam proses pembelajaran matematika berjalan dengan optimal. Pembelajaran matematika seharusnya dikemas semenarik mungkin agar siswa tidak merasa cepat bosan dan mampu termotivasi dalam belajar sehingga mampu menarik minat siswa dalam belajar. Penyajian atau pengungkapan materi matematika di sekolah dasar harus disesuaikan dengan perkiraan perkembangan intelektual peserta didik (Rahmah, 2013: 2).

Guru mempunyai peranan yang sangat penting untuk mencapai tujuan pembelajaran matematika. Guru harus mampu menyesuaikan pembelajaran sesuai dengan perkembangan peserta didik, agar peserta didik mampu memahami konsep matematika yang diberikan oleh guru. Guru sebagai pemegang peran penting dalam kesuksesan proses pembelajaran matematika di kelas harus mampu menguasai dan memahami tujuan dari pembelajaran matematika. Sehingga diharapkan dapat memberikan dampak yang positif terhadap hasil belajar. Hasil belajar merupakan salah satu evaluasi yang dilakukan oleh guru kepada peserta didik dan juga merupakan suatu interaksi tindak belajar dan tindak mengajar. Hal ini sejalan dengan Suhendri (2011: 32) yang menyatakan bahwa Hasil belajar adalah evaluasi dari kegiatan belajar mengajar yang berupa perubahan dalam bentuk kognitif, afektif, dan psikomotor dalam hal kemampuan tentang bilangan, bangun, hubungan-hubungan konsep dan logika yang berkesinambungan serta dapat diukur atau diamati. Sedangkan Susanto (dalam Masa dkk., 2017: 4) menyatakan hasil belajar adalah perubahan-perubahan yang terjadi pada diri siswa, baik yang menyangkut aspek kognitif, afektif, dan psikomotor sebagai hasil kegiatan belajar. Sedangkan menurut Kristin (2016: 92) hasil belajar merupakan puncak keberhasilan belajar siswa terhadap tujuan belajar yang telah ditetapkan. Sehingga dapat disintesiskan bahwa hasil belajar adalah perubahan tingkah laku atau kemampuan yang dimiliki siswa yang mencakup bidang dari segi kognitif, afektif, dan psikomotor siswa terhadap tujuan pembelajaran yang terjadi akibat adanya hasil dari proses belajar.

Hasil belajar merupakan kemampuan yang dimiliki oleh siswa setelah menerima pembelajaran. Kemampuan siswa tidak hanya berupa kemampuan kognitif melainkan juga kemampuan afektif dan psikomotor (Suhendri, 2011: 32). Kemampuan kognitif, afektif, dan psikomotor disebabkan karena pengalaman-pengalaman yang dimiliki siswa saat proses pembelajaran. Sedangkan hasil belajar matematika merupakan hasil atau tingkat penguasaan dari materi atau konsep matematika terutamanya dibidang atau diranah kognitif (Kristin, 2016: 92). Penguasaan materi akan didapat setelah melalui proses belajar matematika yang terlihat dari nilai yang diperoleh setelah diberikan atau dievaluasi dengan tes hasil belajar. 
Setelah dilakukan wawancara, observasi, dan studi dokumen di kelas IV SD Lab Singaraja pada tanggal 28 Oktober 2019, terdapat masalah terutamanya pada hasil belajar matematika siswa. Dalam proses pembelajaran kemampuan pemahaman matematika siswa masih cendrung rendah. Hal ini dikarenakan pembelajaran berlangsung kurang efektif sehingga siswa mengalami kendala ketika menerima atau memahami materi matematika, kurangnya partisipasi serta keaktifan siswa dalam proses pembelajaran, dipertengahan pembelajaran siswa kurang memperhatikan pembelajaran, kurangnya penggunaan media menyebabkan semangat belajar siswa menurun dan cepat bosan sehingga berdampak terhadap hasil belajar siswa, tidak semua peserta didik mampu berkonsentrasi dalam waktu yang relatif lama, dan kemampuan pemahaman peserta didik dalam mata pelajaran matematika berbeda-beda. Dilihat dari hasil studi dokumen yang diperoleh data nilai UTS matematika di kelas IV yang disajikan pada Tabel 1.

Tabel 1. Nilai UTS Matematika Siswa Kelas IV di SD Lab Singaraja Tahun Pelajaran $2019 / 2020$

\begin{tabular}{|c|c|c|c|c|c|}
\hline \multirow[t]{2}{*}{ No } & \multirow[t]{2}{*}{ Kelas } & \multirow[t]{2}{*}{ Jumlah siswa } & \multicolumn{3}{|c|}{ Nilai dan Kriteria } \\
\hline & & & $\begin{array}{c}\text { 60-73 } \\
\text { (Cukup) }\end{array}$ & $\begin{array}{l}74-87 \\
\text { (Baik) }\end{array}$ & $\begin{array}{c}88-100 \\
\text { (Sangat Baik) }\end{array}$ \\
\hline 1 & IV A & 36 & 16 & 9 & 11 \\
\hline 2 & IV B & 34 & 15 & 9 & 10 \\
\hline & & 70 & 31 & 18 & 21 \\
\hline
\end{tabular}

Berdasarkan Tabel 1, dapat dilihat dari 70 sebanyak 31 siswa atau sama dengan $44,29 \%$ mendapat predikat cukup, dari 70 siswa sebanyak 18 siswa atau sama dengan $25,71 \%$ mendapat predikat baik, dan dari 70 siswa sebanyak 21 atau sama dengan $30 \%$ siswa mendapat predikat sangat baik. Hal ini menunjukan bahwa nilai matematika siswa masih beragam dan masih kurang optimal. Jika permasalahan tersebut tetap dibiarkan, maka akan mempengaruhi tingkat keberhasilan belajar siswa. Jika pembelajaran seperti ini tetap diterapkan, maka akan menimbulkan kejenuhan bagi siswa yang nantinya berdampak pada rendahnya hasil belajar siswa. Oleh karena itu, guru dituntut untuk dapat memilih kegiatan pembelajaran yang tepat, agar siswa terhindar dari kebosanan, dan tercipta kondisi belajar yang interaktif, efektif, dan efisien.

Upaya yang dapat dilakukan oleh guru untuk meningkatkan hasil belajar khususnya mata pelajaran matematika di sekolah dasar yaitu dengan menggunakan model-model pembelajaran. Model pembelajaran dapat membantu guru dalam penyampaian materi pembelajaran. Model merupakan "pola umum perilaku pembelajaran untuk mencapai tujuan pembelajaran yang diharapkan" (Wijanarko, 2017: 53). Sedangkan Yuliantini dkk (2017: 3) menyatakan model pembelajaran ialah pola yang digunakan sebagai pedoman dalam merencanakan pembelajaran di kelas maupun tutorial. Penggunaan model pembelajaran yang sesuai dapat membantu guru dalam proses pembelajaran, sehingga permasalahanpermasalahan yang terjadi pada saat pembelajaran berlangsung dapat diatasi.

Salah satu model pembelajaran yang dapat diterapkan atau digunakan adalah model pembelajaran make a match. Model pembelajaran make a match merupakan salah satu model pembelajaran yang dapat diterapkan dalam pembelajaran baik dijenjang dasar maupun lanjut. Model pembelajaran make a match adalah model pembelajaran yang diatur sedemikian rupa sehingga, proses pembelajaran dapat berjalan dengan lebih menyenangkan. Dengan menggunakan model pembelajaran ini, diskusi kelompok dan interaksi antar siswa memungkinkan akan terjadi sharing pengetahuan dan permasalahan-permasalah yang terjadi dari proses diskusi yang berlangsung lebih menyenangkan. Anggarawati dkk (2014: 3) menyatakan, Guru sangat dianjurkan menggunakan model pembelajaran ini bagi anak yang mempunyai tipe malu bertanya kepada guru, karena apabila belajar bersama dengan temanteman, anak tersebut diharapkan tidak malu bertanya kepada temannya sendiri bila ada materi 
yang belum dia mengerti sehingga dapat memotivasi semangat belajar dan berbagi informasi serta pengetahuan antar teman.

Model pembelajaran make a match sangat efektif diterapkan karena dapat melatih siswa dalam mencari pasangan dari kartu jawaban dan soal yang mereka dapatan. Hal ini sejalan dengan pendapat (Shoimin, 2014: 98) yang menyatakan model pembelajaran make a match adalah siswa diminta untuk mencari pasangan kartu yang merupakan jawaban atau pertanyaan materi tertentu dalam pembelajaran. Karena dengan model pembelajran make a match siswa akan termotivasi dalam mengikuti pembelajaran. Model pembelajaran make a match siswa mendapatkan satu buah kartu, siswa memikirkan jawaban atau soal dari kartu yang dipegang, setiap siswa mencari pasangan yang mempunyai kartu cocok dengan kartunya dalam batasan waktu, setelah waktu habis kartu akan kembali dikocok kemudian dibagikan kepada siswa. Model pembelajaran make a match mengaktifkan siswa dengan cara siswa menemukan sendiri jawaban dari soal yang di bawa teman lain dan siswa juga dituntut untuk aktif dalam pembelajaran dan menentukan jawaban yang tepat (Aliputri, 2018: 72). Sehingga, melalui model pembelajaran make a match siswa dapat menemukan jawaban atau pertanyaan dari kartu yang didapat yang nantinya akan dibahas secara bersama-sama. Dengan demikian siswa dapat menyampaikan kesulitan atau permasalahan yang mereka alami dalam proses pembelajaran. Selain itu, dengan model pembelajaran make a match guru dapat melatih kesiapan siswa dalam menyelesaikan dan menanggapi suatu pertanyaan atau masalah. Walaupun begitu, model pembelajaran make a match juga memiliki kelemahan seperti memerlukan waktu yang lama dalam penerapan model pembelajaran ini.

Model pembelajaran make a match memiliki kelebihan dibandingkan dengan model pembelajaran yang lain. Menurut Shoimin (2014: 99) adapun kelebihan dari model pembebelajaran make a match yaitu (1) suasana kegembiraan akan tumbuh dalam proses pembelajaran, (2) kerja sama antar sesama siswa terwujud dengan dinamis, dan (3) munculnya dinamika gotong royong yang merata di seluruh siswa. Aliputri (2018: 75) menyatakan, Hasil belajar dapat meningkat terjadi setelah guru menerapkan model pembelajaran Make A Match, dimana model pembelajaran Make A Match merupakan salah satu model pembelajaran kooperatif yang mengandung unsur permainan didalamnya yaitu saat mencari psangan dari jawaban dalam kartu. Sehingga siswa akan lebih bekerja sama, lebih aktif dan tidak pasif dalam mengikuti pembelajaran di kelas.

Model pembelajaran make a match dapat dipadukan dengan media pembelajaran. Media adalah berbagai bentuk perangkat yang dapat menyajikan pesan serta merangsang peserta didik untuk belajar (Sulfemi \& Mayasari, 2019: 58). Salah satu media yang bisa digunakan untuk menyajikan pesan serta merangsang peserta didik untuk belajar adalah kartu gambar. Kartu gambar adalah media untuk berkomunikasi dengan orang lain (Puspita dkk., 2016: 4). Media kartu gambar merupakan sebuah media pembelajaran yang menghadirkan gambar di dalam media kartu. Media kartu gambar merupakan jenis media visual. Media visual dapat memperlancar pemahaman dan memperkuat ingatan peserta didik (Sudiarsini dkk., 2016: 4). Gambar adalah media yang umum digunakan dalam proses pembelajaran di dalam kelas. Kartu gambar merupakan media pembelajaran yang memberikan pengaruh paling besar bagi indera anak dan lebih membantu anak dalam memahami dan mengingat suatu objek (Utiarahman dkk., 2013: 4). Dengan media kartu gambar, maka pembelajaran akan lebih menarik dan tidak membosankan karena dengan kartu gambar siswa akan lebih tertarik dan lebih semangat dalam pembelajaran. "Melalui gambar siswa dapat menerjemahkan ide-ide abstrak dalam bentuk lebih realistis" (Agustini dkk., 2014: 6).

Penggunaan media gambar dalam proses pembelajaran dapat mengatasi keterbatasan indra kita terhadap objek-objek tertentu. Tidak semua benda, objek atau peristiwa dapat dibawa ke kelas, dan tidak selalu bisa anak-anak dibawa ke objek atau peristiwa tersebut. Media gambar dapat mengatasi keterbatasan pengamatan kita, gambar dapat memperjelas suatu masalah, dalam bidang apa saja dan untuk tingkat usia berapa saja, sehingga dapat mencegah atau menghindari kesalah pahaman, gambar harganya murah dan gampang didapat serta digunakan tanpa memerlukan peralatan khusus (Nonik dkk., 2013: 7). Dengan 
menggunakan media kartu gambar guru akan lebih terbantu dalam menyampaikan pembelajaran di kelas. Selain itu, siswa lebih semangat dalam proses pembelajaran.

Media kartu gambar yang digunakan haruslah sesuai dengan keadaan sebenarnya, gambarnya harus jelas sehingga siswa lebih mudah memahami apa yang dimaksud gambar, dan gambar dalam kartu ukuranya harus sesuai tidak boleh terlalu besar dan tidak boleh terlalu kecil. Menurut Utami (2018: 147) media gambar mempunyai kelebihan mudah didapatkan dan digunakan, murah, jelas, dan dapat mengaktifkan siswa.Kartu gambar dapat membantu guru dalam mencapai tujuan pembelajaran, karena "kartu gambar termasuk media yang mudah dan murah serta besar artinya untuk mempertinggi nilai pembelajaran" (Anggarawati dkk., 2014: 4). Dengan menggunakan media kartu gambar, guru lebih bisa menghemat ruang atau tempat karena media gambar menggunakan ruang atau tempat yang tidak terlalu besar. Adapun langkah-langkah model pembelajaran make a match berbantuan media kartu gambar adalah: (1) Guru menyiapkan beberapa kartu yang berisikan gambar beberapa konsep/ topik yang terdiri dari kartu soal dan jawaban. Guru menyampaikan tujuan pembelajaran yang ingin dicapai dan memotivasi siswa, (2) guru menyampaikan materi kepada siswa, (3) guru membagi siswa menjadi dua kelompok dan menjelaskan langkah-langkah model pembelajaran make a match, (4) guru memberikan siswa masing-masing satu buah kartu pertanyaan/kartu jawaban (kelompok pertama mendapatkan kartu soal dan kelompok dua mendapatkan kartu jawaban atau sebaliknya) lalu siswa memikirkan jawaban/soal dari kartu yang mereka dapatkan. Siswa mencari pasangan dari kartu yang mereka dapatkan. Siswa yang berhasil mendapatkan pasangan kartu sebelum waktu habis akan mendapatkan poin, (5) Guru bersama siswa membahas jawaban maupun soal yang didapatkan masing-masing siswa dan membimbing siswa untuk menarik kesimpulan, dan (6) Guru memberikan poin bagi siswa yang menemukan pasangan kartu sebelum batas waktu yang ditentukan.

Selama ini banyak penelitian yang berfokus pada peningkatkan hasil belajar matematika. Beberapa diantaranya adalah penelitian yang dilakukan oleh Fatimah (2017) yang menunjukkan bahwa kelas yang diterapkan model pembelajaran Make A Match dengan media kartu bergambar dapat meningkatkan hasil belajarsiswa, hal ini dikarenakan model ini menekankan adanya pembelajaran mengenai konsep dengan cara mencari pasangan melalui media kartu bergambar. Penelitian yang dilakukan oleh Pujiati dkk (2018) menghasilkan kesimpulan bahwa model pembelajaran Make A Match efektif terhadap hasil belajar matematika di SD yang dibuktikan dengan peningkatan hasil belajar siswa. Penelitian yang dilakukan oleh Kaharuddin (2018) yang menyimpulkan bahwa penerapan pembelajaran matematika melalui model make a match dalam pembelajaran matematika siswa kelas VI Sekolah Dasar di Kecamatan Marioriwawo sangat efektif ditinjau dari hasil belajar siswa. Penelitian yang dilakukan oleh Anggraeni dkk (2019) yang menunjukkan bahwa penggunaan model pembelajaran kooperatif tipe make a match berpengaruh terhadap hasil belajar siswa mata pelajaran Matematika kelas V SD Negeri 1 Balun Banjarnegara.

Berdasarkan penelitian yang telah dilakukan tersebut dalam meningkatkan hasil belajar matematika dapat dilakukan dengan menerapkan model yang dapat meningkatkan keaktifan siswa pada saat pembelajaran, guna mengetahui dan mengeksplorasi pengetahuan yang mereka dapatkan. Penelitian tersebut masih memiliki kelemahan-kelemahan diantaranya kurangnya penekanan interaksi antara siswa pada saat menerapan model pembelajara. melhat Dengan melihat dan pertimbangan dari penelitian sebelumnya, solusi yang dapat dapat ditawarkan untuk mengatasi rendahnya hasil belajar matematika adalah dengan menerapkan model model pembelajaran Make $A$ Match berbantuan media kartu gambar, model pembelajaran ini sama dengan penelitian sebelumnya yaitu menumbuhkan peran aktif siswa dalam proses pembelajaran. Menurut Anggraeni dkk (2019: 122) pada model pembelajaran Make $A$ Match siswa lebih aktif karena dituntut untuk mencari tahu dengan mengamati (observing) dan mencocokkan pertanyaan dengan jawaban dari kartu yang berisi beberapa topik, saling bekerja sama (networking), mempresentasikan hasil diskusi dengan mengeluarkan pendapat mengenai topik (associating), bertanya (questioning), dan menerima pendapat dari kelompok lain sehingga siswa lebih memahami konsep-konsep yang dianggap sulit karena berdiskusi secara kelompok. Oleh karena itu, model pembelajan make a match bersesuaian dengan pembelajaran matematika yang menuntut siswa aktif serta mampu 
menguasai konsep dari matematika. Model pembelajaran ini diberbantukan dengan media kartu gambar menyesuaikan dengan karakter siswa sekolah dasar yang cendrung aktif untuk bergerak dan menyukai gambar saat proses pembelajaran.

Berdasarkan pemaparan di atas, tujuan dari diadakannya penelitian ini adalah untuk mengetahui pengaruh yang signifikan hasil belajar matematika antara kelompok siswa yang dibelajarkan dengan model pembelajaran make a match berbantuan media kartu gambar dan kelompok siswa yang tidak dibelajarkan dengan model pembelajaran make a match berbantuan media kartu gambar pada siswa kelas IV SD Lab Singaraja Tahun Pelajaran $2019 / 2020$.

\section{Metode}

Penelitian ini dilakukan di SD Lab Singaraja pada siswa kelas IV pada rentang waktu semester II (genap) tahun pelajaran 2019/2020. Jenisspenelitian yang dilakukan adalah penelitian eksperimen. Penelitian ini bertujuan untuk menguji pengaruh model pembelajaran make a match berbantuan media kartu gambar terhadap hasil belajar matematika siswa Kelas IV SD Lab Singaraja. Jenis penelitian ini adalah penelitian eksperimen semu (Quasi Eksperiment). Desain ini dipilih karena tidak memungkinkan mengubah kelas dan tidak mungkin melakukan kontrol terhadap semua variabel lain selain variabel perlakuan. Pelaksanaan penelitian ini menggunakan dua kelas, yaitu kelas eksperimen dan kelas kontrol. Kelas eksperimen dibelajarkan menggunakan model pembelajaran make a match berbantuan media kartu gambar sedangkan kelas kontrol tidak dibelajarkan dengan model pembelajaran make a match berbantuan media kartu gambar. Desain eksperimen semu yang digunakan dalam hal ini adalah "Post test Only Control Group Design".

Populasi dalam penelitian ini adalah seluruh siswa kelas IV yang berada di SD Lab Singaraja Tahun Pelajaran 2019/2020 sebanyak 70 siswa. Populasi terlebih dahulu harus diuji untuk menentukan kesetaraannya dengan menggunakan rumus anava varians satu jalur (ANAVA A). Sebelum menentukan sampel penelitian, dilakukan uji kesetaraan populasi terlebih dahulu guna mengetahui apakah kemampuan siswa kelas IV di SD Lab Singaraja setara atau tidak. Uji kesetaraan kemampuan dilakukan dengan cara menganalisis nilai ulangan tengah semester mata pelajaran matematika tahun pelajaran 2019/2020. Berdasarkan analisis varians dengan uji ANAVA satu jalur, harga $F_{\text {hitung }}$ lebih kecil daripada $\mathrm{F}_{\text {tabel }}(0,51<3,98$, pada taraf signifikansi $5 \%)$, maka $\mathrm{H}_{0}$ diterima dan $\mathrm{H}_{1}$ ditolak. Jadi, tidak terdapat perbedaan yang signifikan hasil ulangan tengah semester pada mata pelajaran matematika siswa kelas IV SD Lab Singaraja. Hal ini membuktikan bahwa, kemampuan siswa kelas IV SD Lab Singaraja dinyatakan setara. Setelah melakukan uji kesetaraan terhadap populasi, selanjutnya dilakukan penentuan sampel penelitian. Sampel adalah "sebagian dari populasi yang diambil, yang dianggap mewakili seluruh populasi dan diambil menggunakan teknik tertentu" (Agung 2014: 69). Menentukan sampel dalam penelitian ini dilakukan dengan cara teknik sampling purposive. Sugiyono (2014:67) menyatakan sampling purposive adalah teknik penentuan sampel dengan pertimbangan-pertimbangan tertentu. Sampling purposive digunakan karena sampel yang digunakan dalam penelitian ini berjumlah dua sampel dan sampel dalam populasi juga berjumlah dua sampel maka tidak bisa menggunakan teknik group random sampling. Dua kelas tersebut kemudian diundi untuk menentukan kelas eksperimen dan kelas kontrol. Pemilihan kelas ekperimen dan kelas kontrol dilakukan dengan cara pengundian. Dari dua kelas yang terpilih, setelah dilakukan pengundian yang menjadi kelas eksperimen adalah siswa kelas IVA SD Lab Singaraja yang berjumlah 36 orang dan siswa kelas IVB SD Lab Singaraja yang berjumlah 34 orang sebagai kelas kontrol. Kelas eksperimen diberikan perlakuan dengan menggunakan model pembelajaran make a match berbantuan media kartu gambar dan kelas kontrol tidak diberikan perlakuan pembelajaran menggunakan model pembelajaran make a match berbantuan media kartu gambar.

Data yang dicari dalam penelitian ini adalah skor hasil belajar pada mata pelajaran matematika kelas IV SD. Metode yang digunakan adalah metode tes. Tes yang digunakan adalah tes pilihan ganda yang terdiri dari 25 butir soal dengan satu jawaban benar. Tes tersebut disusun berdasarkan kisi-kisi soal yang telah dibuat sesuai dengan KD dan indikator 
matapelajaran matematika yang akan dibahas. Materi matematika yang dibahas yaitu mengenai bangun. Adapun materi bangun datar yang dibahas dalam kisi-kisi adalah luas dan keliling persegi, persegi panjang, dan segitiga. Sebelum digunakan untuk mengukur hasil belajar matematika, kisi-kisi yang berupa istrumen akan diuji terlebih dahulu sebuah. Uji intrumen berupa uji validitas isi menggunakan rumus Gregory, validitas butir tes menggunakan rumus korelasi point biserial, reliabilitas tes menggunakan KR-20, daya beda tes, dan tingkat kesukaran tes. Hasil tes uji soal tersebut selanjutnya diberikan kepada siswa kelas eksperimen dan kontrol sebagai post-test.

Metode analisis data yang digunakan dalam penelitian ini adalah metode analisis statistik deskriptif dan statistik inferensial. Menurut Agung (2014: 110) analisis statistik deskriptif adalah suatu cara pengolahan data yang dilakukan dengan jalan menerapkan rumus-rumus statistik deskriptif. Adapun dalam penelitian ini statistik deskriptif yang digunakan yaitu mean, median, modus, dan standar deviasi. Sedangkan statistik inferensial adalah "suatu cara pengolahan data yang dilakukan dengan jalan menerapkan rumus-rumus statistik inferensial untuk menguji suatu hipotesis penelitian yang diajukan peneliti, dan kesimpulan ditarik berdasarkan hasil penguji terhadap hipotesis" (Agung, 2014: 110). Sedangkan teknik yang digunakan untuk menganalisis data guna menguji hipotesis penelitian adalah uji-t. Untuk bisa melakukan uji hipotesis, persyaratan yang harus dipenuhi dan perlu dibuktikan yaitu: (1) data yang dianalisis harus berdistribusi normal, (2) kedua data yang dianalisis harus bersifat homogen. Untuk dapat membuktikan dan memenuhi persyaratan tersebut, maka dilakukanlah uji prasyarat analisis dengan melakukan uji normalitas, dan uji homogenitas.

\section{Hasil dan Pembahasan}

Setelah kelompok ekperimen diberikan perlakuan menggunakan model pembelajaran Make $A$ Match berbantuan Media Kartu Gambar dan kelompok kontrol tidak diberikan perlakuan menggunakan model pembelajaran Make $A$ Match berbantuan Media Kartu Gambar, selanjutnya akan dilakukan pengukuran. Analisis data dilakukan pada masingmasing kelas yaitu kelas ekperimen dan kelas kontrol. Hasil dari analisis data statistik deskriptif disajikan pada Tabel 2.

Tabel 2. Analisis Data dengan Statistik Deskriptif

\begin{tabular}{lcc}
\hline \multirow{2}{*}{ Statistik } & \multicolumn{2}{c}{ Hasil Belajar Matematika } \\
\cline { 2 - 3 } & Eksperimen & Kontrol \\
\hline Mean & 19,47 & 17,59 \\
Median & 19,5 & 17,5 \\
Modus & 20 & 17 \\
Standar Deviasi & 2,72 & 3,10 \\
Varians & 7,40 & 9,64 \\
\hline
\end{tabular}

Berdasarkan Tabel 2, hasil analisis deskriptif hasil belajar Matematika menunjukan bahwa pada sebaran data kelas eksperimen bernilai negatif, karena $\mathrm{Mo}>\mathrm{Md}>\mathrm{M}$ $(20>19,5>19,47)$. Sedangkan sebaran data pada kelas kontrol bernilai positif karena $\mathrm{Mo}<\mathrm{Md}<\mathrm{M}(17<17,5<17,59)$. Dari sebaran data skor hasil belajar Matematika, menunjukkan bahwa sebagian besar nilai kelas eksperimen cenderung tinggi, sementara pada kelas kontrol cenderung rendah. Ketika dikonversikan rata-rata hasil belajar Matematika kelas eksperimen dan kelas kontrol dengan katagori pada skala lima, didapatkan rata-rata skor hasil belajar Matematika siswa pada kelas eksperimen adalah 19,47 termasuk pada kategori tinggi. Sementara hasil rata-rata skor hasil belajar Matematika siswa kelas kontrol adalah 17,59 pada ketegori tinggi.

Setelah dilakukan analisis deskriptif, selanjutnya dilakukan uji hipotesis. Sebelum dilakukan uji hipotesis, terlebih dahulu dilakukan uji prasyarat yaitu uji normalitas dan uji homogenitas. Berdasarkan uji normalitas data menggunakan rumus Chi-kuadrat yang disajikan pada Tabel 3. 


\begin{tabular}{cccccccc}
\hline \multicolumn{6}{c}{ Tabel 3. Rekapitulasi Hasil Pengujian Normalitas Sebaran Data dan } & Homogenitas Varians \\
\hline No & $\begin{array}{l}\text { Kelas } \\
\text { Sampel }\end{array}$ & $\begin{array}{c}\text { Total } \\
\text { Sampel }\end{array}$ & $\boldsymbol{X}^{2}$ hitung & $\boldsymbol{X}^{2}$ tabel & $\mathbf{F}_{\text {hitung }}$ & $\mathbf{F}_{\text {tabel }}$ & Kesimpulan \\
\hline 1 & Eksperimen & 36 & 4,93 & 15,507 & 1,30 & 3,98 & $\begin{array}{c}\text { Normal dan } \\
\text { homogen }\end{array}$ \\
\hline 2 & Kontrol & 34 & 12,92 & 15,507 & 1,30 & 3,98 & $\begin{array}{c}\text { Normal dan } \\
\text { homogen }\end{array}$ \\
\hline
\end{tabular}

Berdasarkan hasil pengujian normalitas sebaran data pada Tabel 3 , menunjukkan bahwa $X^{2}{ }_{\text {hitung }}<X^{2}$ tabel berarti data hasil belajar Matematika kelompok eksperimen berdistribusi normal. Begitu jyga dengan hasil uji normalitas pada kelompok kontrol menunjukkan bahwa $\mathrm{X}^{2}{ }_{\text {hitung }}<\mathrm{X}^{2}$ tabel berarti data hasil belajar Matematika kelompok kontrol berdistribusi normal.

Setelah melakukan uji normalitas, selanjutnya dilakukan pengujian homogenitas. Uji homogenitas dilakukan untuk menentukan bahwa kelas eksperimen dan kelas kontrol yang sudah ditetapkan tersebut memiliki penguasaan yang relatif sama atau homogen. Hasil uji homogenitas kelompok eksperimen dan konrol dinyatakan homogen karena $F_{\text {hit }}<F_{\text {tab }}$ dengan taraf signifikansi $5 \%$. Sehingga dapat disimpulkan skor post-test hasil belajar matematika siswa kelompok ekperimen dan kontrol adalah homogen.

Selanjutnya akan dilakukan uji hipotesis. Kriteria pengujian hipotesis adalah $\mathrm{H} 0$ ditolak jika $\mathrm{t}>$ $p$, dan diperoleh dari tabel distribusi t pada taraf signifikansi $5 \%(p)$, dengan derajat kebebasan $\mathrm{db}=\mathrm{n} 1+\mathrm{n} 2-2$. Hasil uji hipotesis disajikan pada Tabel 4.

Tabel 4. Hasil Uji-T

\begin{tabular}{|c|c|c|c|c|c|c|}
\hline Kelompok & $\mathbf{N}$ & $d b$ & Mean & $\mathbf{S}^{2}$ & $T$ & $p$ \\
\hline Ekperimen & 36 & 68 & 19,47 & 7,40 & 265 & 1905 \\
\hline Kontrol & 34 & & 17,59 & 9,64 & 2,65 & 1,995 \\
\hline
\end{tabular}

Berdasarkan Tabel 4, didapatkan bahwa thitung $>\mathrm{p}$ sehingga $\mathrm{H}_{0}$ diterima dan $\mathrm{H}_{1}$ ditolak. Artinya terdapat perbedaan yang signifikan terhadap hasil belajar Matematika antara kelompok siswa yang dibelajarkan dengan model pembelajaran Make A Match berbantuan media Kartu Gambar dan kelompok siswa yang tidak dibelajarakan dengan model pembelajaran Make A Match berbantuan media Kartu Gambar pada siswa kelas IV SD Lab Singaraja.

Setelah dilakukan analisis penelitian, dan didapatkan hasil bahwa terdapat pengaruh yang signifikan terhadap hasil belajar Matematika antara kelompok siswa yang dibelajarkan dengan model pembelajaran Make A Match berbantuan media Kartu Gambar, dan kelompok siswa yang tidak dibelajarakan dengan model pembelajaran Make A Match berbantuan media Kartu Gambar pada siswa kelas IV SD Lab Singaraja. Hal tersebut dapat dilihat dari perbedaan rata-rata post-test skor hasil belajar dari kelompok eksperimen dan kelompok kontrol. Adapun yang mendasari dari perbedaan tersebut adalah sebagai berikut.

Pertama, model pembelajaran Make A Match berbantuan kartu gambar merupakan model pembelajaran yang menuntut siswa untuk aktif mencari jawaban atau pertanyaan dari kartu gambar yang mereka dapatkan. Model pembelajaran ini dapat merangsang siswa untuk aktif dalam proses pembelajaran, sehingga proses pembelajaran dapat berlangsung dengan optimal. Hal ini sejalan dengan pendapat Anggraeni dkk., (2019: 121) model pembelajaran Make A Match menuntut anak didik aktif dalam proses pembelajaran pembelajaran di dalam kelas. Dalam penerapan model pembelajaran tersebut, guru menjadi fasilitator yang mengarahkan siswa menjadi lebih aktif dan memotivasi siswa untuk memecahkan masalah dari soal yang mereka dapatkan. Dari model pembelajaran Make A Match berbantuan Media Kartu Gambar siswa tidak hanya dituntut agar bisa menerima pebelajaran, akan tetapi siswa juga dituntut untuk aktif dan mau berinteraksi dengan teman-temanya. Model pembelajaran Make $A$ Match merupakan model pembelajaran yang melatih siswa untuk berpikir cepat, berinteraksi dengan teman, berpartisipasi aktif sekaligus membangun konsep dan 
pemahaman mereka sehingga apa yang menjadi tujuan dari pembelajaran akan tercapai (Prihatiningsih \& Setyanigtyas, 2018: 5).

Kedua, media kartu gambar dapat menarik perhatian siswa dan menumbuhkan rasa ingin tau siswa dalam proses pembelajaran. Hal ini dikarenakan kartu gambar berisikan gambar-gambar yang menjadi daya tarik siswa untuk belajar. Kartu gambar akan memberi pengaruh positif, yaitu dapat meningkatkan motivasi belajar, rasa ingin tau dan hasil belajar siswa (Dewi \& Laila, 2015: 175). Hal ini sejalan dengan pendapat Aliputri (2018: 72) media pembelajaran gambar yang juga menjadi faktor pendukung keberhasilan dalam menerapkan model pembelajaran Make A Match, sehingga mampu meningkatkan gairah belajar dan rasa ingin tau siswa. Melalui media kartu gambar, siswa akan lebih tertarik dalam mencari pasangan dari kartu yang mereka dapatkan. Gambar-gambar pada kartu yang digunakan dikreasikan dengan menambahkan gambar baik dari serial kartun, tokoh-tokoh dalam superhero, tokoh-tokoh dalam game, dan tentunya gambar-gambar yang berkaitan dengan materi-materi bangun datar.

Ketiga, model pembelajaran Make A Match berbantuan Media Kartu Gambar dapat meminimalisir kesulitan belajar secara individu yang sering dialami oleh siswa. Hal ini dikarenakan dalam penerapan model pembelajaran ini, aka ada dinamika gotong royong yang merata diseluruh siswa. Gotong royong yang dimaksud adalah, siswa bekerja sama dengan siswa yang lainya atau pasangannya dalam memecahkan masalah yang ada pada kartu pertanyaan maupun kartu jawaban sehingga siswa akan lebih mudah menemukan pasangan dari kartu yang mereka dapatkan. Hal ini sejalan dengan pendapat Gading \& Kharisma (2017: 158) yang menyatakan model pembelajaran kooperatif tipe make a match memungkinkan siswa dapat bekerja sama dengan pasangannya dimana siswa saling berbagi informasi secara kebersamaan. Dalam penerapan model pembelajaran ini siswa dilatih untuk mengembangkan kerjasama untuk dapat pemecahan permasalahan materi yang diberikan oleh guru dalam pembelajaran. Hal ini sejalan denagn pendapat Shoimin (2014: 99) dengan menerapkan model pembelajaran Make $A$ Match dalam proses pembelajaran ada dinamika gotong royong yang muncul di seluruh siswa. Setelah siswa mendapatkan kartu yang dibagikan oleh guru, siswa akan bekerjasama untuk menemukan pasangan dari kartu soal ataupun jawaban yang mereka dapatkan. Siswa nantinya diharapkan dapat menemukan serta mengembangkan kemampuan mereka dalam menemukan soal ataupun jawaban dengan temen mereka. Setelah menemukan pasangan mereka, siswa juga diarahkan gamar menyampaikan hasilnya didepan kelas yang didengarkan atau diperhatikan oleh semua siswa. Sehingga proses pembelajaran didalam kelas tidak lagi berpusat pada guru dan proses pembelajaran tidak membosankan atau monoton. Guru hanya berpran sebagai motivator dan fasilitator, dimana guru memberikan motivasi dan mempasilitasi dan memberian tanggung jawab dalam memecahkan masalah yang didapatkan siswa. Sehingga siswa menjadi lebih aktif dalam proses pembelajaran dan tujuan dari pembelajaran akan tercapai.

Kelebihan lain dari model pembelajaran ini adalah siswa dilatih kecepatanya dalam menyelesaikan sebuah masalah dan mencari pasanganya. Pada penerapan model pembelajaran Make A Match berbantuan Media Kartu Gambar, guru akan memberikan batasan waktu untuk mencari pasangan dari setiap kartu yang didapatkan oleh siswa. Dengan pemberian waktu, siswa akan lebih terpacu dan fokus untuk memecahkan masalah dan mencari pasangan kartu yang didapatkan. Kelompok sisiwa yang dibelajarkan dengan menggunakan model pembelajaran Make A Match berbantuan Media Kartu Gambar, menunjukan hasil yang lebih baik. Sebagian besar siswa sudah aktif dalam proses pembelajaran yang diberikan oleh guru. Siswa sangat antusias dalam pembelajaran, dan mampu bekerjasama dengan siswa lain dalam penerapan pembelajaran dengan model ini. Hal tersebut membuktikan pernyataan Shoimin (2014: 99) bahwa model pembelajaran Make A Match memiliki kelebihan yaitu "(1) suasana kegembiraan akan tumbuh dalam proses pembelajaran, (2) kerjasama antar sesama siswa terwujud dengan dinamis, (3) munculnya dinamika gotong royong yang merata di seluruh siswa. Sedangkan pada kelompok yang tidak dibelajarkan dengan model pembelajaran Make A Match berbantuan Media Kartu Gambar masih cendrung kurang optimal. Proses pembelajaran masih cendrung berpusat pada guru, dimana guru masih menyampaikan banyak materi, latihan soal, dan kadang pemberian tugas 
yang dikerjakan secara berkelompok. Hal ini mengakibatkan siswa kurang aktif dalam proses pembelajaran. Pada saat pemberian post-tes, skor pada kelas kontrol lebih rendah dibandingkan kelas eksperimen yang dibelajarakan dengan model pembelajaran Make $A$ Match berbantuan Media Kartu Gambar. Rendahnya hasil belajar ini dipengaruhi oleh beberapa factor diantaranya, kurangnya melibatkan siswa secara langsung dalam proses pembelajaran, penggunaan model dan media yang kurang optimal dalam proses pembelajaran. Oleh karena itu, penggunaan media dan model yang sesuai sangatlah penting dalam proses pembelajaran.

Berdasarkan temuan yang didapatkan dari kelompok eksperimen maupun kelompok kontrol, hasil belajar matematika yang dibelajarkan dengan model pembelajaran Make $A$ Match berbantuan Media Kartu Gambar lebih daik dibandingkan dengan kelompok siswa yang tidak dibelajarkan dengan model pembelajaran Make $A$ Match berbantuan Kartu Gambar. Hasil penelitian ini juga sejalan dengan penelitian yang dilakukan oleh Yuliantini dkk (2017) bahwa pembekajaran dengan menggunakan model pembelajaran kooferatif tipe Make A Match pada kelas eksperimen, memberikan peluang yang besar pada siswa untuk terlibat aktif dalam proses pembelajaran. Selain itu, siswa tidak merasa bosan dalam proses pembelajaran. Hal yang sama juga ditemukan pada penelitian yang dilakukan oleh Aliputri (2018) yang menyatakan bahwa penerapan model pembelajaran kooperatif tipe Make $A$ Match berbantuan kartu bergambar dapat meningkatkan hasil belajar IPS materi Kegiatan Ekonomi untuk siswa kelas IV SDN Wulung 1 Kabupaten Blora, hal ini dibuktikan dengan ketuntasan hasil belajar siswa

Berdasarkan paparan di atas, maka dapat disintesiskan bahwa terdapat perbedaan yang signifikan terhadap hasil belajar Matematika antara kelompok siswa yang dibelajarkan dengan model pembelajaran Make A Match berbantuan Media Kartu Gambar dan kelompok siswa yang tidak dibelajarakan dengan model pembelajaran Make $A$ Match berbantuan Media Kartu Gambar pada siswa kelas IV SD Lab Singaraja.

\section{Simpulan}

Berdasarkan analisis data yang telah dilakukan dapat disimpulkan bahwa penerapan model pembelajaran Make A Match berbantuan Media Kartu Ganbar berpengaruh terhadap hasil belajar matematika siswa kelas IV SD Lab Singaraja. Berdasarkan penelitian yang dilakukan, adapun saran yang dapat diberikan yaitu untuk siswa SD agar lebih aktif dalam proses pembelajaran sehingga dapat lebih fokus dan mampu memahami materi-materi mata pelajaran, guru diharapkan dapat menggunakan inovasi baru dalam pembelajaran salah satunya dengan menggunakan model-model pembelajaran dan media-media yang cocok, salah satu yang bisa dicoba adalah model pembelajaran Make $A$ Match berbantuan Media Kartu Gambar, kepala sekolah diharapkan menyediakan fasilitas-fasilitas dalam menunjang proses pembelajaran didalam kelas, sehingga proses pembelajaran akan berjalan lebih optimal, dan Bagi peneliti lain diharapkan dapat dijadikan pedoman untuk penelitian, serta dapat digunakan sebagai bahan referensi dalam penelitian sejenis yang dilaksanakan. Penelitian selanjutnya hendaknya dapat mengembangkan hasil penelitian baik dalam ranah kognitif maupun ranah psikomotor untuk penyempurnaan penelitain yang akan dilaksanakan.

\section{Daftar Pustaka}

Agung, A. A. G. (2014). Buku Ajar Metodologi Penelitian Pendidikan. Yogyakarta: Aditya Media Publishing.

Agustini, N. L. E., Agung, A. A. G., \& Suarni, N. K. (2014). Pengaruh Model Pembelajaran Artikulasi Berbantuan Media Kartu Gambar untuk Meningkatkan Kemampuan Bahasa Anak TK. Jurnal Pendidikan Anak Usia Dini Undiksha, 2(1).

Aliputri, D. H. (2018). Penerapan Model Pembelajaran Kooperatif Tipe Make A Match Berbantuan Kartu Bergambar untuk Meningkatkan Hasil Belajar Siswa. Jurnal Bidang Pendidikan Dasar, 2(1A), 70-77.

Anggarawati, I. G. A. A., Kristiantari, M. R., \& Asri, I. G. A. A. S. (2014). Pengaruh Make a Match Berbantuan Kartu Gambar terhadap Hasil Belajar IPA SD. Mimbar PGSD 
Undiksha, 2(1).

Anggraeni, A. A., Verliana, P., \& Fakthu, I. R. (2019). Pengaruh Model Pembelajaran Kooperatif Tipe Make a Match terhadap Hasil Belajar Matematika Siswa Kelas IV SD. International Journal of Elementary Education, 3(2), 218-225.

Dewi, R. N. L., \& Laila, A. (2015). Pengaruh Metode Make a Match dengan Media Gambar terhadap Kemampuan Mengenal Kekhasan Bangsa Indonesia Seperti Kebhinekaan Siswa Kelas III SDN Purwodadi Kec. Kras Kab. Kediri Tahun Ajaran 2015. TERAMPIL: Jurnal Pendidikan Dan Pembelajaran Dasar, 2(2).

Fatimah, I. D. (2017). Penerapan Model Pembelajaran Make a Match dengan Media Kartu Bergambar untuk Meningkatkan Motivasi dan Hasil Belajar Siswa. Ilmu Pendidikan: Jurnal Kajian Teori Dan Praktik Kependidikan, 2(1), 28-37.

Gading, I. K., \& Kharisma, K. D. (2017). Pengaruh Model Pembelajaran Kooperatif Tipe Make a Match Berbantuan Media Audio Visual Terhadap Hasil Belajar Ips Sekolah Dasar. International Journal of Elementary Education, 1(2), 153-160.

Kaharuddin, A. (2018). Keefektifan Model Make A Match dalam Pembelajaran Matematika Siswa Kelas VI Sekolah Dasar di Kecamatan Marioriwawo. Jurnal Pendidikan Dan Pembelajaran Dasar, 11(1), 12-23.

Kristin, F. (2016). Analisis Model Pembelajaran Discovery Learning dalam Meningkatkan Hasil Belajar Siswa SD. Jurnal Pendidikan Dasar PerKhasa, 2(1), 90-98.

Masa, N., Murda, I. N., \& Mahadewi, P. L. P. (2017). Pengaruh Model Make a Match terhadap Hasil Belajar IPS Siswa SD. Mimbar PGSD Undiksha, 5(2), 1-10.

Nonik, N. N., Raga, I. G., \& Murda, I. N. (2013). Penerapan Metode Demonstrasi dengan Media Kartu Gambar untuk Meningkatkan Kemampuan Kognitif Anak Kelompok A di PAUD Widya Dharma Bondalem Tejakula. Pendidikan Anak Usia Dini Undiksha, 1(1), 1-11.

Novitasari, D. (2016). Pengaruh Penggunaan Multimedia Interaktif terhadap Kemampuan Pemahaman Konsep Matematis Siswa. FIBONACCI: Jurnal Pendidikan Matematika Dan Matematika, 2(2), 8-18.

Prihatiningsih, E., \& Setyanigtyas, E. W. (2018). Pengaruh Penerapan Model Pembelajaran Picture and Picture dan Model Make a Match terhadap Hasil Belajar Siswa. Jurnal Pendidikan Sekolah Dasar, 4(1), 1-14.

Pujiati, S. S., Damayani, A. T., \& Basyar, M. A. K. (2018). Keefektifan Model Tipe Make a Match Terhdadap Hasil Belajar Matematika Kelas II Semester 2 SD Negeri Ngeling 01 Jepara. Jurnal Sekolah, 2(4), 315-319.

Puspita, P. M., Wirya, I. N., \& Aditya, P. A. (2016). Penerapan Pendekatan Saintifik Berbantuan Media Kartu Gambar untuk Meningkatkan Kemampuan Berbicara di TK Catur Paramita. Jurnal Pendidikan Anak Usia Dini Undiksha, 4(2).

Rahmah, N. (2013). Hakikat Pendidikan Matematika. Al-Khwarizmi: Jurnal Pendidikan Matematika Dan IImu Pengetahuan Alam, 1(2), 1-10.

Shoimin, A. (2014). Model Pembelajaran Inovatif dalam Kurikulum 2013. Yogyakarta: Ar-Ruzz Media.

Sudiarsini, M., Agung, A. A. G., \& Parmiti, D. P. (2016). Pengaruh Model Pembelajaran Kooperatif STAD Berbantuan Media Visual terhadap Hasil Belajar IPA Kelas V SD. MIMBAR PGSD Undiksha, 4(1).

Sugiyono. (2014). Metode Penelitian Kualitatif, Kuantitatif, dan R\&D. Bandung: Alfabeta.

Suhendri, H. (2011). Pengaruh Kecerdasan Matematis-Logis dan Kemandirian Belajar terhadap Hasil Belajar Matematika. Formatif: Jurnal IImiah Pendidikan MIPA, 1(1), 2939.

Sulfemi, W. B., \& Mayasari, N. (2019). Peranan Model Pembelajaran Value Clarification Technique Berbantuan Media Audio Visual untuk Meningkatkan Hasil Belajar IPS. Jurnal Pendidikan, 20(1), 53-67.

Susanto, A. (2013). Teori Belajar dan Pembelajaran di Sekolah Dasar. Jakarta: Kencana Prenada Media Group.

Utami, S. (2018). Penggunaan Media Gambar untuk Meningkatkan Motivasi Hasil Belajar IPA Siswa Kelas III Sekolah Dasar. Primary: Jurnal Pendidikan Guru Sekolah Dasar, 7(1), 137-148. 
Utiarahman, W., Madina, R. L., \& Samsiah. (2013). Peran Guru dalam Penggunaan Media Kartu Gambar di Kelompok B TK Pembina Desa Bunoyo Kecamatan Paguat Kabupaten Pohuwato. Skripsi, 1(153407168).

Wijanarko, Y. (2017). Model Pembelajaran Make a Match untuk Pembelajaran IPA yang Menyenangkan. Jurnal Taman Cendekia, 1(1), 52-59.

Yuliantini, K., Agung, A. A. G., \& Wibawa, C. I. M. (2017). Pengaruh Make a Match Berbantuan Kartu Teka Teki terhadap Hasil Belajar IPS Siswa Kelas IV. Mimbar PGSD Undiksha, $5(2), 1-10$. 